\title{
Experimental Study on Behaviour of Concrete by Replacement of Aggregate and Sand with Rubber Tyre Chips and Foundry Sand
}

\author{
Abhishek Raulkar, Vikas Khade, Prof. J. H. Gurnani, Jayant P. Anjankar, Abhishek Wasnik, Mayuri Deo
}

Department of Civil Engineering, Nagpur Institute of Technology, Nagpur, Maharashtra, India

\begin{abstract}
Concrete is the most important civil engineering material in construction buildings and industries because increase the strength properties. Rubber and foundry sand are produced excessively worldwide every year. In such a case the reuse of rubber and foundry sand would be a better choice. In order to reuse rubber wastes, rubber tyre chips was added to concrete as coarse aggregate and In order to reuse foundry sand, foundry sand was added to concrete as fine aggregate and its different properties like compressive strength. As a result it was found that rubberized and foundry sand concrete is durable, less ductile, has greater crack resistance but has a low compressive strength when compared with ordinary concrete. Due to rapid growth in automobile industry use of tyre increase day to day and there is no reuse of the same to decrease the environmental pollution .in this paper we will study about physical and mechanical properties of concrete containing recycled tyre or rubber material aggregate. This study present the information about the civil engineering application of foundry sand, which is technically sound and is environmental safe. Foundry sand can be used as a partial replacement of fine aggregate and rubber tyre chip partial replacement coarse aggregate foundry sand can be used in concrete to improve its strength and other durability factor. Foundry sand is high silica sand that is a by - product from the production of both ferrous and non-ferrous metal casting. The fresh $\&$ hardened properties of concrete such as workability, compressive strength, are the identified.
\end{abstract}

Keywords: Rubber Tyre Chips, Foundry Sand, Workability, Compressive Strength of Concrete.

\section{INTRODUCTION}

A large variety of materials are considered feasible and valuable additive for concrete. Waste of rubber tyre is a harmful to the environment. The management of waste tyre rubber is challenger to municipalities. A rubber obtained from scrapped tyre is considered as the recent waste materials are vital use in the construction field. This creates a major problem for the earth \& their living. The investigation show that the rubber tyre material are the do not decompose. Concrete is the most commonly used construction material in civil engineering and cement, sand, aggregate is economical and easily available in market. The disposal of waste tyre landfill is legally banned in all the countries due to environmental impact.

The environmental condition is the various problems. India has been recycling \& reusing waste tyres for 4 decades. Although it is estimated that $60 \%$ are disposed of through dumping. Scrap tyre is not only waste but also costly. The production of rubber increases every year. The rubber tyre chips are used to replace by gravel. 
Concrete is normally use in frame structure; utilization of waste solid materials is one of the most challenging problem growth of the world of population. The industrial sand, waste tyre rubber chips .Waste rubber tyre is a huge task to the industries and public sectors, decomposing of waste rubber tyre which contains composed of materials and it cause serious contamination for environmental condition. The discharge of waste tyres is expensive and the continuously decreasing numbers of landfills generates significant pressure to the local authorities identifying the potential application for this waste products. One of the largest potential routes is in construction, but usage of waste tyres in civil engineering is currently very low. As the use and production of rubber is increasing day by day with the increase of population.

The physical \& chemical characteristics of foundry sand and rubber tyre will depend in great patron the type of casting process \& the industry sector from which is originates. The cement of high strength concrete is generally high which often leads to higher shrinkage and greater evaluation of heat of hydration besides increase in cost.

Cement: - Cement in general, adhesive substances of all kinds, but, in a narrower sense, the binding materials used in building and civil engineering construction. Cements of this kind are finely ground powders that, when mixed with water, set to a hard mass. Because of their hydrating properties, constructional cements, which will even set and harden under water, are often called hydraulic cements. The most important of these is Portland cement.

Course Aggregate: - The technique of Sieve Analysis is used for gradation of aggregate for use in concrete and for other applications. Aggregate is called bound material when it is mixed with cement or binding materials and referred to as unbound material when used without cement or binding materials. Aggregates are commonly obtained by crushing naturally occurring rock. Aggregates are evaluated through tests to determine their suitability for various applications. Mineralogy, grain size and texture, and petrography description of rock samples are also used to evaluate suitability.

Fine Aggregate: - Aggregate is the granular material used to produce concrete or mortar and when the particles of the granular material are so fine that they pass through a $4.75 \mathrm{~mm}$ sieve, it is called fine aggregate. It is widely used in the construction industry to increase the volume of concrete, thus it is a cost saving material and you should know everything about the fine aggregate size, its density and grading zone to find the best material. Fine aggregate is the essential ingredient in concrete that consists of natural sand or crushed stone. The quality and fine aggregate density strongly influence the hardened properties of the concrete.

Rubber Tyre Chips: - A large variety of waste materials are considered feasible and even much valuable additives for concrete. Some of these materials include cellulose, fly ash and wood particles. Rubber obtained from scrapped tyres is considered as the most recent waste materials that have been examined because of its vital use in the construction field. Similarly, discarded vehicle tubes are one of the important solid waste challenges to handle \&disposal needing more useful applications than just becoming a material for land filling. Due to the rapid depletion of available sites for waste disposal, many countries discourage the disposal of waste tube rubber in landfills and encourage in the construction sector to use these waste materials in concrete in place of fine or coarse aggregate. Usually three main categories of discarded tyre rubber have been considered such as 
chipped, crumb and ground rubber. Chipped or shredded rubber is used to replace the gravel.

Foundry Sand: - Foundry sand is high quality silica sand that is a by-product from the production of both ferrous and nonferrous metal castings. The physical and chemical characteristics of foundry sand will depend in great part on the type of casting process and the industry sector from which it originates Foundry sand is basically fine aggregate. It can be used in many of the same ways as natural or manufactured sands. This includes many civil engineering applications such as embankments, flow able fill, hot mix asphalt (HMA) and Portland cement concrete (PCC). At present, although a great attention to environmental issues, the general trend is still to dispose UFSs in landfills, sometimes utilized as landfill daily cover. Several evident drawbacks could be listed due to this trend Early closure of the material life cycle with consequently more consumption of virgin raw materials Saturation of existing landfills and soil pollution in unmanaged landfill cases Release of leachable contaminants, absorbed by the sand during the mounding process and casting Operations, like heavy metals (cadmium, lead, copper, nickel, and zinc) and phenols Economic impact, referring in particular to logistic costs in UFS transportation sometimes landfill is not so close to the foundry. A foundry is a manufacturing facility that produces metal castings by pouring molten metal into a preformed mould to yield the resulting hardened cast. Foundry sand is high quality silica sand that is a by- product from the production of both ferrous and non-ferrous metal castings.

\section{METHODS AND MATERIAL}

Strength is one among the most important properties of concrete, since the first consideration in structural design is that the structural members must be capable of carrying the imposed loads. The mix of concrete used in this study is M20. Concrete mix the percentages of replacements are $0 \%, 10 \%, 20 \%, 30 \%$ \& $40 \%$ (S1, S2, S3, S4, S5). Tests were performed for compressive strength of concrete for all replacement levels at different curing period (7 days and 28 days).

In this experimental investigation consists of different mix proportions by replace coarse aggregate and sand in $0,10,20,30$ and $40 \%$ of waste rubber tyre and foundry sand in M20 grade concrete. Total numbers of 30 cubes $(150 \times 150 \times 150 \mathrm{~mm})$ were casted for durability test as well as optimum compressive strength test. After that cubes were immersed into water until the curing period. Compressive strength test was performed at the age of 7 and 28 days. Compressive strength calculated using compressive strength machine.

1. Machine Mixing: - A concrete mixer often colloquially called a cement mixer is a device that homogeneously combines cement, aggregate such as sand or gravel, and water to form concrete. A typical concrete mixer uses a revolving drum to mix the components. For smaller volume works, portable concrete mixers are often used so that the concrete can be made at the construction site, giving the workers ample time to use the concrete before it hardens.

2. Weight Batching: - In this method, Materials are measured on the basis of weight. It is accurate method of batching Weigh batchers or other types of weighing equipment are used to measure weight of materials. Cement, fine aggregate, coarse aggregate and water are taken by weighing. Weight batch used are available in two types namely mechanical weigh batcher and electronic weigh batchers. In mechanical weigh batchers, weights are measured using spring and dial gauge arrangement and it is widely used equipment in weigh batching. In electronic weigh batchers, electronic scales and load cells supported by 
hoppers are used to measure the weight of ingredients of concrete. Weigh batchers available are may be Manual or semi-automatic or fully automatic. Manual type is used for small concrete production job while other two types are used for large concrete production.

\section{Procedure}

First of all, wet the inner surfaces of the drum of concrete mixer.

$\checkmark$ Coarse aggregates are placed in the mixer first followed by sand cement foundry sand and rubber tyre chips.

$\checkmark$ Mix the materials in the dry state in the mixing machine. Normally it should be 1.5 to 3 minutes.

$\checkmark$ After proper mixing of dry materials, gradually add the correct quantity of water while the machine is in motion. Do not add more water than required. It is not advisable as it reduces strength.

$\checkmark$ After adding the water, you must mix concrete for a minimum of two minutes in the drum.

$\checkmark$ If there is any segregation of concrete after unloading from the mixer, then remix the concrete.

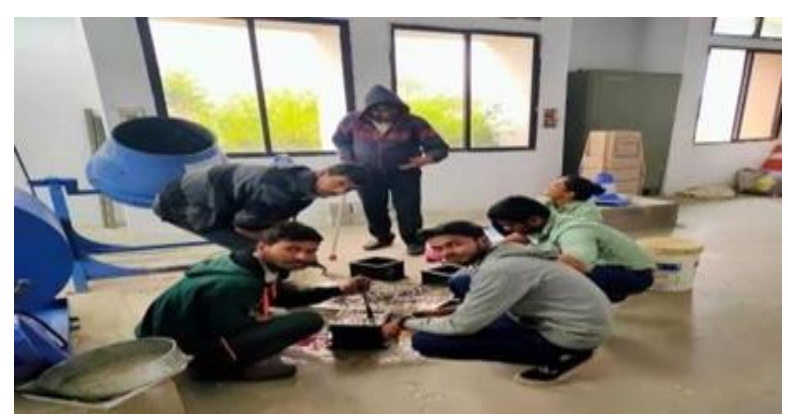

\section{Procedure for Casting of Cubes:}

$\checkmark$ Clean the standard cube moulds thoroughly and tight all nuts bolts properly.

$\checkmark$ Apply oil to all contract surface of mould. $\checkmark$ Size of mould is normally 150X150x150 mm Take the random sample from the mixing spot while concreting.

$\checkmark \quad$ Fill the concrete in cube.

$\checkmark$ Compact each layer with 35 strokes per layer for $150 \mathrm{~mm}$ moulds, using a tamping rod. 4 corners of cube mould must receive 7 strokes and 7 strokes at centre of cube mould. Each layer must be compacted allowing the rod passes into the underlying layer also and the bottom most layers must be compacted throughout its depth.

$\checkmark$ Remove the surplus concrete after the mould is fully filled. Level the top surface and smoothen it with a trowel.

$\checkmark$ Mark the cube surface with an identification number (say as 1, 2, 3 etc.) with a nail or match stick and record these numbers in respect with the concrete truck and location of pour where the sampled concrete is obtained.

$\checkmark$ Cover the mould by damp hessian cloth immediately to prevent loss of water.

$\checkmark$ Each specimen should be taken from various locations of proposed concreting.

$\checkmark$ After 24 hours remove specimen out of mould.

$\checkmark$ While removing, take care to avoid breaking of edges.

$\checkmark$ Put coding on cubes by paints or marker, coding should be self-explanatory showing site name, concrete location, building Number and date of casting.

$\checkmark$ Submerge the specimen in clean fresh water till the time of testing.

$\checkmark \quad$ Test 7 days and 3 specimens for 28 days curing.

\section{CALCULATIONS}

M20 grade of concrete (Ratio 1:1.5:3) 1 cement, 1.5 sand, 3 aggregate

Replacement ratio of concrete with foundry sand and rubber tyre chips is $0 \%, 10 \%, 20 \%, 30,40 \%$. 
Total of cube: 36

S1 ( $0 \%$ of foundry sand and rubber tyre chips): 6 cubes

S2 (10\% of foundry sand and rubber tyre chips): 6 cubes

S3 (20\% of foundry sand and rubber tyre chips): 6 cubes

S4 (30\% of foundry sand and rubber tyre chips): 6 cubes

S5 (40\% of foundry sand and rubber tyre chips): 6 cubes

Volume of cube $(6$ cubes $)=0.00675 \mathrm{~m}^{3}$

$=1+1.5+3=5.5$

Vol. $=1.57^{*} 0.00675$

$=0.0105975 \mathrm{~m}^{3}$

Cement:

Vol. of cement $=1 / 5.5^{*} 0.0105975$

$=0.0019268 \mathrm{~m}^{3}$

Density of cement $=1440 \mathrm{~kg} / \mathrm{m}^{3}$

$\mathrm{Kg}$ of cement $=0.00578045^{*} 1440$

$=8.32385 \mathrm{~kg}$.

Sand:

Vol. of sand $=1.5 / 5.5^{*} 0.0317925$

$=0.008670681 \mathrm{~m}^{3}$

Density of sand: $1600 \mathrm{~kg} / \mathrm{m}^{3}$

$\mathrm{Kg}$ of sand $=0.008670681^{*} 1600=13.87309 \mathrm{~kg}$

Aggregate:

Vol. of aggregate $=3 / 5.5^{*} 0.0317925$

$=0.01734136 \mathrm{~m}^{3}$

\section{Density of aggregate $=1750 \mathrm{~kg}$}

Kg of aggregate $=0.01734136^{*} 1750$

$$
=30.3473 \mathrm{~kg}
$$

\section{Foundry sand \& Rubber tyre chip (20-25mm):}

1) M2 (10\% of foundry sand and rubber tyre chips)

(6 cubes)

\section{Foundry sand:}

Vol. of sand $=0.008670681 \mathrm{~m}^{3}$

$10 \%$ of sand volumes $=0.000867068 \mathrm{~m}^{3}$

Density of foundry sand $=1203.34 \mathrm{~kg} / \mathrm{m}^{3}$

Kg of foundry sand $=0.000867068^{*} 1203.34$

$$
=1.0433776 \mathrm{~kg}
$$

\section{Rubber tyre chips:}

Vol. of aggregate $=0.01734136 \mathrm{~m}^{3}$

$10 \%$ of rubber tyre chip $=0.001734136 \mathrm{~m}^{3}$

Density of rubber tyre chip $=940 \mathrm{~kg} / \mathrm{m}^{3}$

Kg of rubber tyre chips $=0.001734136^{*} 940$

$$
=1.6300 \mathrm{~kg}
$$

2) M3 (20\% of foundry sand and rubber tyre chips) ( 6 cubes)

Foundry sand:

Vol. of sand $=0.008670681 \mathrm{~m}^{3}$

$20 \%$ of sand volumes $=0.001734136 \mathrm{~m}^{3}$

Density of foundry sand $=1203.34 \mathrm{~kg} / \mathrm{m}^{3}$

Kg of foundry sand $=0.001734136^{*} 1203.34$

$$
=2.086 \mathrm{~kg}
$$

\section{Rubber tyre chips:}

Vol. of aggregate $=0.01734136 \mathrm{~m}^{3}$

$20 \%$ of rubber tyre chip $=0.003468272 \mathrm{~m}^{3}$

Density of rubber tyre chip $=940 \mathrm{~kg} / \mathrm{m}^{3}$

Kg of rubber tyre chips $=0.003468272 * 940$

$$
=3.26017 \mathrm{~kg}
$$

M4 (30\% of foundry sand and rubber tyre chips) (6 cubes)

\section{Foundry sand:}

Vol. of sand $=0.008670681 \mathrm{~m}^{3}$

$30 \%$ of sand volumes $=0.002601204 \mathrm{~m}^{3}$

Density of foundry sand $=1203.34 \mathrm{~kg} / \mathrm{m}^{3}$

Kg of foundry sand $=0.002601204^{*} 1203.34$

$$
=3.1301 \mathrm{~kg}
$$




\section{Rubber tyre chips:}

Vol. of aggregate $=0.01734136 \mathrm{~m}^{3}$

$30 \%$ of rubber tyre chip $=0.0052024 \mathrm{~m}^{3}$

Density of rubber tyre chip $=940 \mathrm{~kg} / \mathrm{m}^{3}$

Kg of rubber tyre chips $=0.005202^{*} 940$

$$
=4.8898 \mathrm{~kg}
$$

3) M5 (40\% of foundry sand and rubber tyre chips) (6 cubes)

\section{Foundry sand:}

Vol. of sand $=0.008670681 \mathrm{~m}^{3}$

$40 \%$ of sand volumes $=0.003468272 \mathrm{~m}^{3}$

Density of foundry sand $=1203.34 \mathrm{~kg} / \mathrm{m}^{3}$

$\mathrm{Kg}$ of foundry sand $=0.003468272^{*} 1203.3$

$$
=4.1735 \mathrm{~kg}
$$

\section{Rubber tyre chips:}

Vol. of aggregate $=0.01734136 \mathrm{~m}^{3}$

$40 \%$ of rubber tyre chip $=0.006936544 \mathrm{~m}^{3}$

\section{Density of rubber tyre chip $=940 \mathrm{~kg} / \mathrm{m}^{3}$}

Kg of rubber tyre chips $=0.006936544^{*} 940$

$$
=6.52035 \mathrm{~kg}
$$

\section{Water Cement/Content Ratio:}

Assume w/c ratio is 0.5 Water content ratios for 6 cubes:-

$\mathrm{W} / \mathrm{C} .=0.5 * 8.32385=4.162$ Litre

Volume of water cement ratio $=$ volume of cement*Density

$$
\begin{aligned}
& =0.00578045 * 1440 \\
& =8.3238 \mathrm{Kg} \\
& =8.3238 / 4.162 \\
& =1.999 \approx 2.000
\end{aligned}
$$

Total Water Content $=2 \times 4.162=8.324$ litres of water.
Calculation Table:

\begin{tabular}{|c|c|c|c|c|c|}
\hline $\begin{array}{r}\text { Sr. } \\
\text { No. }\end{array}$ & $\begin{array}{c}\text { Cement } \\
(\mathrm{Kg})\end{array}$ & $\begin{array}{c}\text { Sand } \\
(\mathrm{Kg})\end{array}$ & $\begin{array}{c}\text { Aggregate } \\
(\mathrm{Kg})\end{array}$ & $\begin{array}{c}\text { Foundry } \\
\text { Sand } \\
(\mathrm{Kg})\end{array}$ & $\begin{array}{c}\text { Rubber } \\
\text { Tyre } \\
\text { Chips } \\
(\mathrm{Kg})\end{array}$ \\
\hline M1 & 8.3238 & 13.8730 & 30.3473 & ----- & ------- \\
\hline M2 & 8.3238 & 12.4857 & 27.4029 & 1.0433 & 1.6300 \\
\hline M3 & 8.3238 & 11.0984 & 24.3678 & 2.086 & 3.2601 \\
\hline M4 & 8.3238 & 9.7111 & 21.3331 & 3.1301 & 4.8898 \\
\hline M5 & 8.3238 & 8.3238 & 18.2983 & 4.1735 & 6.5203 \\
\hline
\end{tabular}

\section{LITERATURE VIEW AND RESULTS}

\section{A. Literature View}

1. Senthil V. Thiyagarajan, THENMRZHI R (2012) the usage of waste tyres in civil engineering is currently very low. Ali and Ali (1996) found the elevation of properties and failures characteristics of Portland cement concrete field with different content of find rubber chips. He found that the concrete was more slip resistance, highly elastic, lighter in weight and could be used for fire proofing, water proofing and insulation.

2. K K Wagh, et.al, (2014) to investigate the performance of the fresh concrete hard concrete the fine aggregate replace by foundry sand. The result of this investigation showed that mix Up to $40 \%$ replace by foundry sand and showed about 10\% higher compressive strength at 28 days.

3 Venkatesh P, S.A.Vengadesh Subramaniam (2015) to study the waste tyre as partial replacement of fine aggregate to crumb rubber .The different partially replacement crumb rubber is a $0 \%, 10 \%, 20 \%, 30 \%$ and $40 \%$ by volume the casted of cylindrical cube and beam and test of flexural strength and split tensile strength. The increases the percentage crumb rubber in concrete to decreases the strength of concrete.

4. PranitaBhandari, Dr.K.M. Tajne (2016) the foundry sand normally of a higher quality than the typical bank run for natural sands used in full construction sites. It is compost of naturally occurring material which is blended together. High quality silica sand 
(85-95\%), betonies clay $(4-10 \%)$ as a binder .It is black in colour due to carbon content.

5. Zunaithur Rahman. D. Jeyamugesh. S. Sivaranjani. S.\& Vijayaraghavan. J. (2016) rubber tyre chips are a waste material that is ideal for use in concrete applications. This has an additional advantage of saving in natural aggregates used in production of concrete which are becoming increasingly scarce. In this essence, our present study aims to use of waste rubber tyre as partial replacement of coarse aggregate to produce rubberize concrete in M20 grade of mix. Different partial replacements of rubber chips $(0,10$, 20 and $30 \%$ ) by volume of coarse aggregates are casted and tested for compressive strength in water as well as in acid curing on 14 and 28 days. The results show that, $10 \%$ of rubber waste gives higher compressive strength. For usage waste tyres in civil engineering is currently very low and its one of largest potential routes in construction. Depends on its examinations, another way is using the tyres in concrete.

6. Mr. Chothe Onkar K, Mr. V.S.Kadam, Mr. Patil Vikram, Mr. Patil Pravin (2016) solid waste management has most important because tyre rubber waste is increasing at a fast rate. Tyre rubber waste is non-biodegradable nature so that it's used as a fuel in many industries which is not environment friendly. Concrete has notice as an alternative source of recycling the tyre rubber waste. For that concrete mixed with shredded rubber on $0,10,20,30,40 \%$ of course aggregate and workability, compressive strength for 7, 14, 28days and unit weight measured.

7. Mr.S.S.jadhav, Dr.S.N.Tande, Mr.A.C.Dubal (2017) the utilization of used of foundry sand in concrete. The normal concrete mix was proportional to achieve a 28 days of compressive strength 38 mpanad the other concrete mixes the $25 \%$ \& $35 \%$ by weight regular concrete sand with clean /new foundry sand \& used foundry sand. At the 28 days concrete containing used of foundry sand .The test result is $0-0 \%$ lower value than normal concrete but concrete contain $25 \%$ \& $35 \%$ new/clean foundry sand gave almost same compressive strength as that of the control mix.
8. Jk Lakshmipat, et.al, (2017) to investigate the properties of concrete mixture in which the fine aggregate are the partially replace with used of foundry sand with the percentage of $10 \%, 20 \%, 30 \%$ and $40 \%$ by weight. The properties of fresh concrete are performance by the test.

9. Yunus Ballim, T. Gupta (2017) the specific gravity of chipped rubber aggregates is lower as compared to natural aggregates therefore decrease the unit weight of rubber mix concrete. Increasing chipped rubber aggregates as partial replacement into concrete reduces compressive strength. On the other hand, demand of concrete as construction material from society, it is needed to preserve natural coarse aggregate by using alternative material. In this research, reuse of waste tyre chipped rubber in concrete as partial replacement as coarse aggregates. In this process we used the replacement of sand and aggregate ratio is $0,10,20,30,40 \%$ with respect to foundry sand and rubber tyre chips respectively.

10. Naveen Arasu, Robinson J. (2018) in foundry industry during the casting process a large amount of by- product material is produced. The metals which usually cast in foundry industry are cast iron, steel, aluminium, copper, brass and bronze. Over two third of the total by- product material consists of silica and the one third of the total by-product material consists of metals which is casted on the sand. In foundry industry they use high quality silica sand for moulding the metals and also for casting purposes. Compression test has been done to find out the compressive strength of concrete at the age of 7,14 , 21 and 28 days.

11. Mr.Manju. G. S, Rohit Ray, Anusha. B, Manjunatha.K.S (2018) there is a need to develop appropriate techniques of construction, which are economical and affordable .Towards this end, Reinforced concrete structures construction technique has been developed. The testing was done using "COMPRESSION TESTING MACHINE" to know the Compressive Strength \& Split tensile 
Strength of RC structures at curing ages 7, 14 \& 28 days. Waste challenges to handle \& disposal needing more useful applications than just becoming a material for land filling.

12. Sulagno Banerjee, , Dr. Jessyrooby (2019) properties of fresh concrete like workability, compressive strength, split tensile strength of hardened concrete were identified. The aim is to investigate the optimal use of waste tyre rubber as coarse aggregate in concrete composite. For this purpose, there are a number of laboratory tests on prepared specimens and the results so obtained have been analysed suitably. Concrete, the ingredients of which are cement, aggregates (sand, stone-chips) is the most important material in construction work. Hence, there is a high demand for those materials in the commercial sector. It is known fact that in general aggregates used in concrete are obtained by mining. Unfortunately mining causes severe environmental damages by lowering the ground water table.

\section{IV.RESULT}

From the compressive test which had been performed on 30 concrete cubes $(150 \mathrm{mmx} 150 \mathrm{mmx} 150 \mathrm{~mm})$, following result is obtained.

1. Average compressive strength of concrete cube with $0 \%$ foundry sand and rubber tyre chips for 7 days has been obtained as15.659Mpa.

2. Average compressive strength of concrete cube with $10 \%$ foundry sand and rubber tyre chips for 7 days has been obtained as14.0667Mpa.

3. Average compressive strength of concrete cube with $20 \%$ foundry sand and rubber tyre chips for 7 days has been obtained as14.533Mpa.

4. Average compressive strength of concrete cube with 30\% foundry sand and rubber tyre chips for 7 days has been obtained as $16.85 \mathrm{Mpa}$.

5. Average compressive strength of concrete cube with $40 \%$ foundry sand and rubber tyre chips for 7 days has been obtained as $14.067 \mathrm{Mpa}$.
6. Average compressive strength of concrete cube with $0 \%$ foundry sand and rubber tyre chips for 28 days has been obtained as $20.786 \mathrm{Mpa}$.

7. Average compressive strength of concrete cube with $10 \%$ foundry sand and rubber tyre chips for 28 days has been obtained as $21.93 \mathrm{Mpa}$.

8. Average compressive strength of concrete cube with $20 \%$ foundry sand and rubber tyre chips for 28 days has been obtained as24.13Mpa.

9. Average compressive strength of concrete cube with 30\% foundry sand and rubber tyre chips for 28 days has been obtained as $26.167 \mathrm{Mpa}$.

10. Average compressive strength of concrete cube with $40 \%$ foundry sand and rubber tyre chips for 28 days has been obtained as23.77 Mpa.

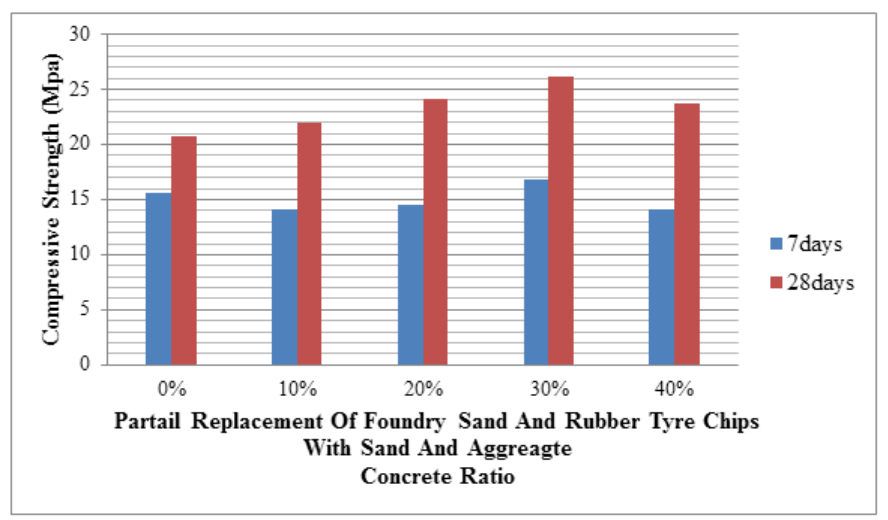

Figure 1: Compressive Strength of Mixes at Various Ages

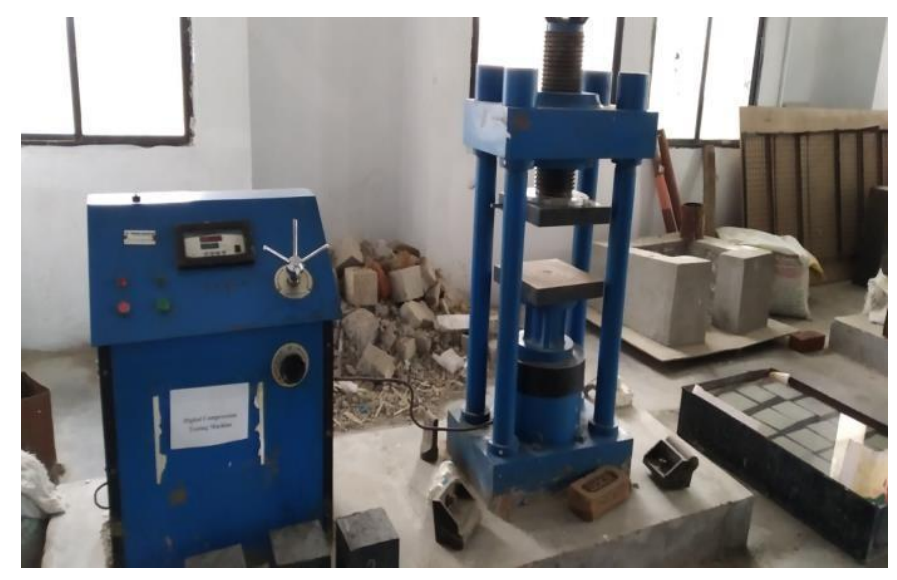

Figure 2 : Compression Testing Machine 


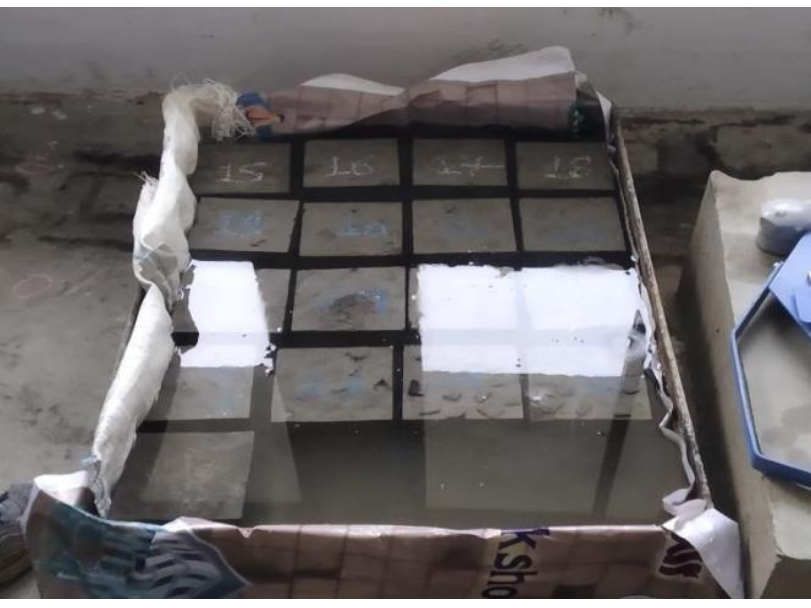

Figure 3 : Curing Of Cubes

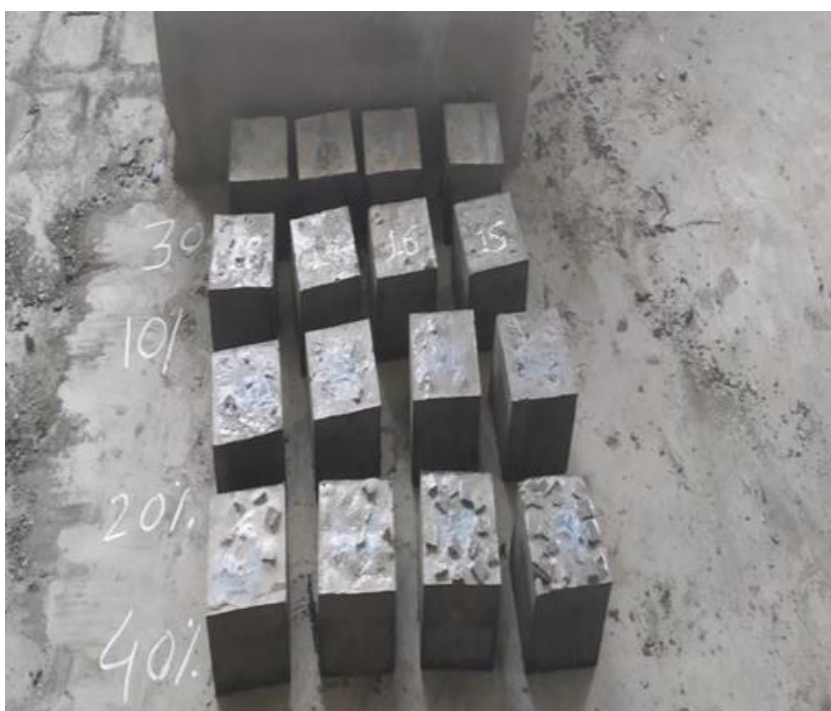

Figure 4 : Casting of Cubes

\section{v. CONCLUSION}

1. Foundry sand and rubber tyre chip has pozzolanic traits and thus can be classified as pozzolana.

2. The available waste product from rubber tyre chips industry i.e., rubber tyre chips can be used successfully to achieve properties in fresh state. As it is finer material helps in avoiding segregation and promotes sustainability of resources.

3. The measured slump values of foundry sand and rubber tyre chips concrete with constant water cement ratio 0.5 are found to be $40,46,48,64$ and $78 \mathrm{~mm}$ for different mixes such as S1 ( $0 \%$ foundry sand and rubber tyre chips), S2 (10\% foundry sand and rubber tyre chips), S3 (20\% foundry sand and rubber tyre chips), S4 (30\% foundry sand and rubber tyre chips), S5 (40\% foundry sand and rubber tyre chips) respectively.

4. The compressive strength of concrete mixes at 7 days is found to be $15.659,14.0667,14.533,16.85$ and $14.067 \mathrm{Mpa}$.

5. The compressive strength of concrete mixes at 28 days is found to be 20.786, 21.93, 24.13, 26.167 and 23.77Mpa.

\section{REFERENCES}

[1] Senthil V. Thiyagarajan, THENMORZHI R (2012), "Experimental study on waste tyre rubber replaced concrete and ecofriendly: Construction material", Journal of Applied Sciences Research, June 2012.

[2] K K Wagh (2014), "Effect of Chipped Rubber Aggregate on Performance of Concrete", American Journal of Engineering Research (AJER), Voume-03, Issue- 12.

[3] Venkatesh P, S.A.Vengadesh Subramaniam (2015), "Utilization of used Foundry Sand and Waste Tyre Rubber in Self Compacting Concrete", International Journal for Innovative Research in Science \& Technology, Volume 1, Issue 11, April 2015.

[4] PranitaBhandari, Dr.K.M.Tajne (2016), "Use of Foundry Sand in Conventional Concrete", International Journal of Latest Trends in Engineering and Technology (IJLTET)Volume 6, issue 3, January 2016. 
[5] Zunaithur Rahman. D. Jeyamugesh. S. Cite this article as :

Sivaranjani. S. and Vijayaraghavan. J. (2016).

"Study on Waste Rubber Tyre in Concrete for

Eco-friendly Environment", Journal of

Abhishek Raulkar, Vikas Khade, Prof. J. H. Gurnani,

Engineering and Technology, Volume 1:5, December 2016.

[6] Mr. Chothe Onkar K, Mr. V.S.Kadam, Mr. Patil Vikram, Mr. Patil Pravin (2016). "EFFECT OF REPLACEMENT OF COURSE AGGREGATE BY SCRAP TYRE RUBBER: EXPERIMENTAL STUDY”, International Journal Research of Engineering and Technology, Volume 03, Issue 05, May 2016.

[7] Mr.S.S.jadhav,Dr.S.N.Tande,Mr.A.C.Dubal(2017 ),"Be neficial Reuse of Waste Foundry Sand in Concrete", International Journal of Scientific and Research Publications, Volume 7, Issue 3, March 2017.

[8] Jk Lakshmipat (2017), "USE OF WASTE IN CONCRETE”, International Research journal of Engineering and technology (IRJET), Volume: 04 Issue: 10, Oct-2017.

[9] Yunus Ballim, T. Gupta (2017). “A Review of Waste Rubber Tyre As An Alternative Concrete",American Journal of Engineering Research, Volume 03, Issue 12, March 2017.

[10] Naveen Arasu, Robinson J. (2018). "Experimental analysis of waste foundry sand in partial replacement of fine aggregate in concrete",International Journal of Chem Tech Research, Volume 10, April 2018.

[11] Mr. Manju. G. S, Rohit Ray, Anusha. B, Manjunatha.K.S (2018). "Experimental Study on Behaviour Of Concrete Using Different Technique",International Journal of Engineering Research and Technology, Volume 7, Issue 05, May 2018.

[12] Sulagno Banerjee, Dr. Jessyrooby (2019). "Strength study of Tyre Rubber Concrete",International Journal of Research in Advanced Technology, Volume 7, April 2019. 